\title{
IMPLEMENTASI STORYTELLING PADA ANAK UMUR 3-5 TAHUN SEBAGAI UPAYA STIMULASI PERKEMBANGAN
}

\author{
Dwi Retnowati ${ }^{1}$ \\ ${ }^{1}$ STIKes Hutama Abdi Husada Tulungagung \\ dwiretnowati@stikestukungagung.ac.id
}

\begin{abstract}
ABSTRAK
Storytelling merupakan suatu proses kreatif anak-anak yang dalam perkembangannya senantiasa mengaktifkan bukan hanya aspek intelektual saja tetapi juga aspek kepekaan, kehalusan budi, emosi, seni, daya berfantasi, dan imajinasi anak yang tidak hanya mengutamakan kemampuan otak kiri tetapi juga kemampuan otak kanan. Berbicara mengenai storytelling, secara umum semua anak-anak senang mendengarkan storytelling, baik anak balita, usia sekolah dasar, maupun yang telah beranjak remaja bahkan orang dewasa. Tujuan penelitian untuk mengetahui pengaruh kegiatan storytelling terhadap tumbuh kembang anak usia 3-5 tahun di TK/KB Petra Kediri. Desain penelitian menggunakan pre eksperimental. Tehnik pengambilan sampel total sampling dengan jumlah sampel 30 responden. Uji Statistik menggunakan wilcoxon sign rank test dengan $\alpha=0,05$.Penelitian ini diketahui bahwa dari 30 responden sebelum diberikan storytelling mengalami tumbuh kembang meragukan sebanyak 27 anak (90\%) dan 3anak (10\%) mengalami tumbuh kembang menyimpang, sedangkan sesudah diberikan storytelling mengalami tumbuh kembang sesuai sebanyak 20 anak (66,7\%) dan sebesar 10 anak $(33,3 \%)$ mengalami tumbuh kembang meragukan. Kesimpulan diperoleh nilai $\mathrm{p}=0,000$ dengan $\alpha=$ 0,05 dimana $\mathrm{p}<\alpha$ sehingga Ho ditolak yang artinya ada pengaruh kegiatan storytelling terhadap tumbuh kembang anak.Hasil penelitian setelah dilakukan kegiatan storytelling di dapatkan bahwa ada pengaruh terhadap tumbuh kembang anak. Di harapkan guru di KB-TK Petra kediri untuk meningkatkan kegiatan storytelling.
\end{abstract}

Kata Kunci : Storytelling, Tumbuh kembang, Anak Usia 3-5 Tahun.

\section{STORYTELLING IMPLEMENTATION IN AGE CHILDREN 3-5 YEARS AS A DEVELOPMENT STIMULATION EFFORTS}

\begin{abstract}
Storytelling is a creative process of children who in its development always activates not only intellectual aspects but also aspects of sensitivity, refinement, emotion, art, fantasy power, and imagination of children who not only prioritize left brain abilities but also the ability of the right brain. Speaking of storytelling, in general all children love to listen to storytelling, both toddlers, elementary school age, and those who have grown up even adults. The purpose of the study was to determine the effect of storytelling activities on the growth of children aged 3-5 years in Petra Kediri Kindergarten / KB. The research design uses pre experimental. Total sampling technique with a sample of 30 respondents. The Statistical Test used the Wilcoxon sign rank test with $\alpha=0.05$. This study found that of the 30 respondents before being given storytelling, there were 27 children (90\%) and 3 children (10\%) experiencing deviant growth and development, while after being given storytelling. experienced growth and development according to as many as 20 children (66.7\%) and as many as 10 children (33.3\%) experienced dubious growth growth. Conclusions obtained p value = 0,000 with $\alpha=0.05$ where $p<a$ so that Ho is rejected, which means there is the influence of storytelling activities on child growth and development. The results of the research after storytelling activities are found that there is an influence on child development. It is expected that caregivers at Petra Kediri Kindergarten will improve storytelling activities.
\end{abstract}

Keywords: Storytelling, Growing, Children 3-5 years old

\section{INTRODUCTION}

Storytelling is a creative process of children who in its development always activates not only intellectual aspects but also aspects of sensitivity, refinement, emotion, art, fantasy power, and imagination of children who not only prioritize left brain abilities but also the ability of the right brain. Speaking of 
storytelling, in general all children love to listen to storytelling, both toddlers, elementary school age, and those who have moved into adolescence and even adults (Asfandiyar, 2007). Prosocial behavior is a form of behavior that arises in social contact, so prosocial behavior is an action carried out or planned to help others regardless of helper motives. Helping actions are fully motivated by their own interests without expecting anything for themselves. Prosocial actions are more demanding at the expense of the offender and are voluntary or more indicated to benefit others than to get material or social rewards.

Child development is a very continuous process, which starts from the womb to adulthood. In the child's development process there are critical times, during which time a stimulation that functions is needed so that the child's potential develops. Child development will be optimal if there are social interactions that suit the needs of children at various stages of development (Adriana: 2013).

According to UNICEF in 2011 data obtained still high incidence of disruption of growth and development in children aged under five, especially motor development disorders found (25.5\%) or 3 million children experiencing disorders. Toddlers in Indonesia About 15\% reported experiencing developmental disorders in the form of intelligence disorders due to disorders of brain development, hearing loss and motor disorders (Ministry of Health, 2015). In 2014 the disruption of growth and development in children in Indonesia reached $35.7 \%$ and was classified as a high public health problem according to $W H O$ reference because it was still above 30\% (Riskesdas, 2012). A child can experience developmental delays in only one realm of development, or can be in more than one developmental domain. Delay in general development or global developmental delay is a state of developmental delay that is significant in two or more areas of development. Approximately 5 to $10 \%$ of children are estimated to experience developmental delays. Data on the incidence of general developmental delays are not known with certainty, but it is estimated that around $13 \%$ of children under the age of 5 experience a general developmental delay (IDAI, 2013)

\section{METHOD}

The research design used in this study was Pre Experimental research with the One-GroupPre-test-posttest Design model. In this model, before the treatment, the initial test or pretest is used to measure the initial condition, then treated and compared. Finished treatment was given another test as posttest. In this study the population was all students at the Petra Kediri $T K-K B$ numbering 30 children conducted on January 1, 2019. The independent variable of the research is storytelling activities. Dependent variable is child development. Before giving a storytelling activity a KPSP test (Pre test) was carried out, then given a $10 x$ storytelling treatment within 20 days. Once the story tells the duration of about 5-7 minutes, after 10x storytelling is given KPSP test (Post test).

To determine whether there is influence of Storytelling activities on 3-5 years old growth and development in TK-KB Petra Kediri using computers with SPSS techniques (Statistical Product and Service Solution Version 16 Windows). To find out the significant level of variables in measuring the influence that is significant with significance level is $p<0.05$, it means that $\mathrm{HO}$ is accepted and $\mathrm{HI}$ is rejected, meaning there is an influence between the measured variables, if $p>0.05$ means $H 0 O$ is rejected and $\mathrm{H} \mathrm{I}$ is accepted.

\section{RESULT}

Table 1.

Age $(n=30)$

\begin{tabular}{ccc}
\hline Age & $f$ & $\%$ \\
\hline 3 & 2 & 6,7 \\
4 & 13 & 43,3 \\
5 & 15 & 50 \\
\hline
\end{tabular}

Based on table 1, it can be seen the age of the respondents from 3-5 years, the highest while for the age of 4 years $43.3 \%$, and for the age of 3 years $6.7 \%$ number is the age of 5 years which is 50\%, 
Jurnal Keperawatan Jiwa Volume 7 No 1 Hal 7 - 12, Mei 2019

FIKKes Universitas Muhammadiyah Semarang bekerjasama dengan PPNI Jawa Tengah

Table 2.

Growth of children aged 3-5 years (PreTest) $(n=30)$

\begin{tabular}{|c|c|c|}
\hline Growth of children aged 3-5 years & 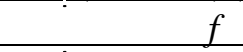 & $\%$ \\
\hline Doubt & 27 & 90 \\
\hline Deviate & 3 & 10 \\
\hline
\end{tabular}

Table 3.

Growth of children aged 3-5 years (PostTest) $(n=30)$

\begin{tabular}{llll}
\hline Growth of children aged 3-5 years & $f$ & $\%$ \\
\hline Coresponding & 20 & \multicolumn{2}{c}{66,7} \\
\hline Doubt & 10 & 33,3 & \\
\hline $\begin{array}{l}\text { Based on table 3, it can be seen that the } \\
\text { growth of respondents before being given the }\end{array}$ & $\begin{array}{l}\text { most storytelling is in the appropriate } \\
\text { category, which is 66.7\%. }\end{array}$
\end{tabular}

Table 4.

Frequency distribution before and after storytelling activities on the growth of children aged 3-5 years $(n=30)$

\begin{tabular}{lcccc}
\hline \multirow{2}{*}{ Categoriez } & \multicolumn{2}{c}{ Before } & \multicolumn{2}{c}{ After } \\
\cline { 2 - 5 } & $f$ & 0 & $f$ & $\%$ \\
\hline Coresponding & 0 & 90 & 10 & 66,7 \\
Doubt & 27 & 10 & 0 & 33,3 \\
Deviate & 3 & 0 \\
\hline
\end{tabular}

4 it is known that from 30 respondents before being given storytelling experienced growth and development doubts as many as 27 (90\%) children and 3 (10\%) children experience deviant growth and development. Whereas after being given storytelling experienced growth and development according to as many as 20 (66.7\%) children and by 10 (33.3\%) children experiencing dubious growth and development.

\section{DISCUSSION}

Development of children aged 3-5 years before being given storytelling activities.

The results of the study on children aged 3-5 years before getting the storytelling, from 30 respondents found that those who experienced dubious growth and development were 27 children (90\%) and those who experienced growth and development deviated as many as 3 children (10\%). Based on cross tabulation in appendix 12, it is known that growth in children aged 36 months before getting storytelling in getting as many as 15 children (50\%) experienced dubious growth and development, while cross tabulation of child storytelling was 18 children (60\%) experience dubious growth growth.

The results of this study can be seen through aspects of child development, among others, gross motorism (gross motor) is a skill that includes large muscle activity such as arm movements and walking. Fine motor Skills are physical skills that involve small muscles and eye and hand coordination that require careful coordination. Language (language) is the ability to respond to sounds, follow orders and speak spontaneously. In language development begins to be able to call up to four images, mentioning one to two colors, mentioning the use of objects, counting, interpreting two words, imitating various sounds, understanding prohibitions and so on (Hidayat, 2009). Social behavior (personal social) are aspects that are related to independent abilities, socializing and interacting with their environment.

The process of Acceleration and Deceleration Child growth can be influenced by several factors, such as racial or ethnic factors, namely children born of the race / nation of America, then it does not have race / nation 
Indonesian hereditary factors / vice versa. Age is the speed of rapid growth in the prenatal period, the first year of life and adolescence. Gender namely reproductive function in girls develops faster than boys, but after passing puberty, the growth of boys will be faster. Research conducted on 3-5 years old children at Petra Kediri Kindergarten and KB before getting many storytelling still experienced dubious growth and development, this was influenced by several factors. At Petra Kediri $T K-K B$ the majority were male

\section{Development of children aged 3-5 years after being given Storytelling activities.}

The results of this study in children aged 3-5 years after getting the storytelling, from 30 respondents found that those who experienced growth and development according to as many as 20 children (66.7\%) and those who experienced growth growth doubted as many as 10 children (33.3\%). The pattern of normal growth and development is not always the same, because it is influenced by interactions by various factors, one of which is external factors (from outside). External factors can be seen from prenatal factors, including nutrition, mechanics, toxins / chemicals, endocrine, radiation, infections, immunological disorders.

Factors of labor, namely complications of labor in infants such as head trauma, aphasia can cause damage to brain tissue.According to Echols (in aliyah, 2011) storytelling consists of two words, namely story means story and telling means telling. Combining two words storytelling means telling stories or telling stories. Storytelling is an art that describes actual events as well as fiction and can be delivered using pictures or sounds, while other sources say that storytelling is a description of life that can be ideas, beliefs, personal experiences, learning about life through a story (Serrat, 2008 ). In accordance with the theory and the fact that storytelling is an interesting thing for children. This is evident when storytelling activities took place, children in the Mother's Child Care Center

\section{Effect of storytelling activities on the growth and development of children aged 3-5 years. The results of the research conducted by researchers for 20 days at Petra Kediri Kindergarten- $K B$ as many as 30 respondents}

before being given the storytelling found that 27 children (90\%) who experienced dubious growth and who deviated from growth and development 3 children (10\%) and after given storytelling, it was found that experienced growth and development according to as many as 20 children (66.7\%) and those who experienced growth growth doubted as many as 10 children (33.3\%). The results of statistical tests using the Wilcoxon Signed Rank Test where the level of significance or $a=$ 0.05 obtained Pvalue $=0,000$ so that Value $<\alpha$ or 0,000 <0.05, it can be concluded that $\mathrm{HO}$ is rejected, $\mathrm{HI}$ is accepted. So, it can be concluded that there is a significant influence between the effect of storytelling activities on the growth of children aged 3-5 years in the KB-TK Petra Kediri.

Storytelling is very useful as stated by Loban (in Aliyah, 2011) stating that storytelling can be a motivation for developing awareness, expanding the imagination of children, parents or activating storytelling activities on various occasions such as when children are playing. There are several aspects of a child's development, including fine motor skills, which are physical skills that involve small muscles and eye and hand coordination that require careful coordination (Papilia, Old \& Feldman, 2010). Language (language) is the ability to respond to sounds, follow orders and speak spontaneously. In language development begins to be able to call up to four images, mentioning one to two colors, mentioning the use of objects, counting, interpreting two words, imitating various sounds, understanding prohibitions and so on (Hidayat, 2009). Gross motor is a skill that includes large muscle activity such as arm movements and walking (Santrock, 2011). Social behavior (personal social) are aspects that are related to independent abilities, socializing and interacting with their environment (Hidayat, 2009).

\section{CONCLUSIONS AND SUGGESTIONS}

\section{Conclusion}

Development of children aged 3-5 years before being given storytelling experienced dubious growth and development as many as 27 children (90\%) and 3 children (10\%) experienced deviant growth and development. 
Development of children aged 3-5 years after being given storytelling experienced growth and development according to as many as 20 children (66.7\%) and 10 children (33.7\%) experienced dubious growth growth. The results of data analysis using the Wilcoxon Signed Rank Test about the effect of storytelling activities on the growth of children aged 3-5 years at Petra Kediri Kindergarten and $K B$ which are statistically significant, namely Value $=0,000$ or Pvalue smaller than $\alpha$ (Value < $\alpha)$, so that HO is rejected, which means there is an influence of storytelling activities on the growth and development of children aged 3-5 years at TK-KB Petra Kediri.

\section{Suggestions}

The results of the research after storytelling activities are found that there is an influence on child development. It is expected that caregivers at Petra Kediri Kindergarten will improve storytelling activities.

\section{BIBLIOGRAPHY}

Andriana. D. (2013). Tumbuh kembang \& Terapi Bermain Pada Anak. Jakarta: Salemba Medika

Asfandiyar, Andi Yudha, (2007). Cara Pintar Mendongeng, Jakarta: Mizan.

Apriadi, Sandi. (2009). Bagian Ilmu Penyakit Anak Jurnal Fakultas Kedokteran. Bandung.

A.Aziz Alimul Hidayat. (2005). Pengantar Ilmu Keperawatan Anak 1. Jakarta Salemba medika.

A.Aziz Alimul Hidayat. (2008). Pengantar Ilmu Kesehatan Anak Untuk Pendidikan Kebidanan. Jakarta: Salemba Medika.

Bunanta, Murti, (2009). Buku, Dongeng, dan Minat Baca, Jakarta: Murti Bunanta Foundation.

Fristi Widya, dkk. "Perbandingan Tumbuh Kembang Anak Toddler Yang Diasuh Orang Tua Dengan Diasuh Selain Orang Tua". Program Studi Ilmu Keperawatan Universitas Riau.
Hidayat, A.A. (2007), Metode Penelitian Keperawatan dan teknik Analisa Data: Penerbit Salemba Medika.

Istiadi, Irawati, (2005). Agar Anak Asyik Belajar, Bekasi: Pusaka Inti.

Kusumastuti Nurcahyani D. (2010). Pengaruh Kegiatan Storytelling Terhadap Pertumbuhan Minat Baca Siswa Di TK Bangun 1 Kec. Pabelan Kab.Semarang

Masfiroh, Tadkiroatun. (2008). Cerdas Melalui Bermain. Jakarta: Grasindo

Nur Chamidah Atien. (2009). "Deteksi Dini Gangguan Pertumbuhan dan Perkembangan Anak". Jurnal Pendidikan Khusus.Vo. 5.No. 2.

Santrock. (2011). Perkembangan Masa Hidup Jilid. 1 edisi kelima. Jakarta: Penerbit Erlangga.

Serrat,O. (2008). Storytelling. United Stases Of America: Reed Elsevier. 
Jurnal Keperawatan Jiwa Volume 7 No 1 Hal 7 - 12, Mei 2019

FIKKes Universitas Muhammadiyah Semarang bekerjasama dengan PPNI Jawa Tengah 